\author{
土戸哲 明
}

関西大学化学生命工学部生命·生物工学科

\title{
Several Aspects of Microbial Technology for Food Pasteurization and Sterilization
}

\author{
Tetsuaki TSUCHIDO \\ Department of Life Science and Biotechnology, Faculty of Chemistry, Materials and Bioengineering, Kansai University \\ 3-3-35 Yamate-cho, Suita, Osaka 564-8680, Japan
}

\begin{abstract}
The results obtained from our studies on several aspects of food pasteurization and sterilization by cross-talk between microbiology and technology were presented. First, we found that the thermal death of Escherichia coli was affected by rising temperature and pre-incubation processes and it was suggested that the phase transition and phase separation of membrane lipids were involved in these phenomena. Second, we analyzed the kinetics of bacterial death by a combined treatment of heating with antimicrobial compounds and we presented two distinct modes depending upon the type of chemicals. Third, new methods for process evaluation and prediction of pasteurization effects, including the growth-delay analysis, the cell motion analysis and the analysis with the fluorescence of green fluorescent protein variants expressed in bacterial cell were proposed. And finally, we constructed the database of thermal death of microorganisms based upon the data which have appeared in articles published in 30 major academic journals. Also, some predictive models on the thermal death of bacterial spores in a buffer and liquid foods were predicted as influenced by several factors such as $\mathrm{pH}$, the sodium chloride concentration and heating temperature.
\end{abstract}

Keywords: pasteurization, sterilization, food, microbiology, technology.

1.はじめに

殺菌には微生物学的な側面と工学的な側面があり, 前者ではその直接の対象が微生物であるのに対し，後 者では，食品などの物質や諸環境の空間という場ない し系である，その意味で，前者では微視的な見方でと らえられ，後者は巨視的な立場で考えられるといえよ う [1]. したがって，現場に打ける殺菌方法の選択や条 件設定には，微生物の耐性という生物的情報と装置や 殺菌手段に関する特性や処理時の負荷量という物理的・ 化学的情報の双方が必要になる。

今回の受賞対象と目される食品殺菌における微生物 工学的研究は, 上記の 2 つの分野間のクロストークに よってより緻密な殺菌の条件設定・プロセス評価やそ

(受付 2009 年 9 月 28 日, 受理 2009 年 11 月 4 日)

=564-8680 大阪府吹田市山手町3-3-35

FAX: 06-6388-8609, E-mail: ttsuchi@ipcku.kansai-u.ac.jp
れらの方法論の開発を企図して行ったものである。こ の融合領域の成果はまだわずかであるが，ここではそ れらを含む微生物工学的視点から検討を進めた主な研 究の概要を紹介する. なお, 別途進めてきた純微生物 学的ないし生化学的な研究の成果 [1]については対象 外とした.

\section{2. 加熱殺菌における昇温過程の解析}

加熱殺菌は必ず非定温過程を伴うが，この過程にお ける微生物の耐性変動について検討された例は 1970 年 代当時ほとんど見出せなかった。筆者ら [2-5] は，マ イクロ波の急速加熱による殺菌効果の解析の検討から 派生して, 大腸菌について一定の加熱温度に至るまで の非定温過程における昇温速度および一定の非致死温 度での予備保温温度の影響を検討し，以下の現象を見 出した。

$37^{\circ} \mathrm{C}$ で培養した大腸菌 $\mathrm{K} 12$ の野生株 OW6 を緩衝液 


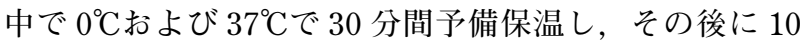
倍希釈法（予め加熱保温した緩衝液 $18 \mathrm{ml}$ に菌懸濁液 2 $\mathrm{ml}$ を注入する方法）によって $50^{\circ} \mathrm{C}$ や $55^{\circ} \mathrm{C}$ に急速加熱す ると，その一定温度での加熱過程に打ける死滅速度が 予備保温温度に依存し， $37^{\circ} \mathrm{C} よ り も 00^{\circ} \mathrm{C}$ 方が大であっ た（Fig. 1)．これを予備保温効果とよび，その要因に ついて，予備保温温度と培養温度を変えて解析した結 果, 細胞膜脂質の相転移・相分離が関与していること が判明した (Fig. 2).すなわち, $37^{\circ} \mathrm{C}$ 培養の大腸菌では, ゲル相の出現が起こり始める温度は $22^{\circ} \mathrm{C}$ たりで，そ

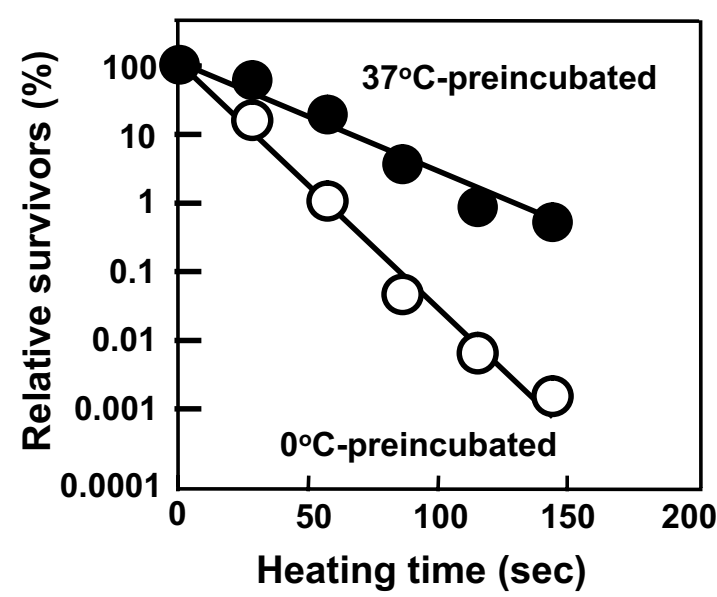

Fig. 1 Preincubation effect on the thermal death of $E$. coli at $50^{\circ} \mathrm{C}$. Cells grown at $37^{\circ} \mathrm{C}$ were harvested, washed, preincubated at $0^{\circ} \mathrm{C}(\bigcirc)$ or $37^{\circ} \mathrm{C}(\bigcirc)$ for $30 \mathrm{~min}$ and then heated to $50^{\circ} \mathrm{C}$ with 10 -fold dilution method in $50 \mathrm{mM}$ potassium phosphate buffer at $\mathrm{pH}$ 7.0.

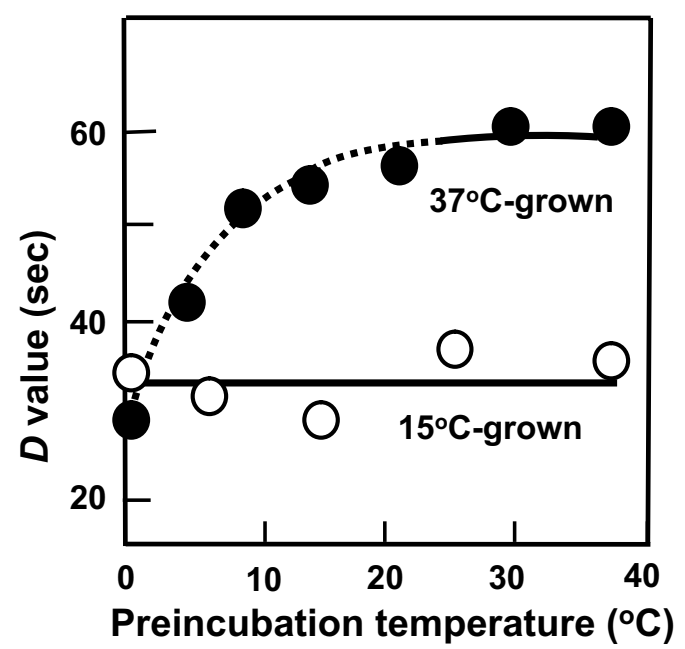

Fig. 2 Thermal death at $50^{\circ} \mathrm{C}$ of $E$. coli cells grown at different temperatures after preincubaion at various temperatures. Cells were grown at $37^{\circ} \mathrm{C}(\bullet)$ or $15^{\circ} \mathrm{C}(\bigcirc)$, preincubated for $30 \mathrm{~min}$ and then heated to $50^{\circ} \mathrm{C}$ with 10 -fold dilution method in $50 \mathrm{mM}$ potassium phosphate buffer at $\mathrm{pH}$ 7.0. Solid and broken parts of line suggest the temperature ranges for the homogeneous liquid-crystalline phase and the phase separation state including the gel phase of membrane lipids, respectively.
れから $0{ }^{\circ} \mathrm{C}$ までの温度範囲では低温になるほど細胞表面 上のゲル相の面積が増加するが，細胞の加熱後の生存 性（耐熱性）はほぼこの挙動に呼応して変化した。 $22^{\circ} \mathrm{C}$ 以上では膜脂質はすべて液晶相にあり，耐熱性も これに対応して一定であった。一方，膜脂質の不飽和 脂肪酸が増えて細胞膜の流動性が上昇することが知ら れている $15^{\circ} \mathrm{C}$ 培養の細胞の膜脂質は，0〜37 ${ }^{\circ} \mathrm{C}$ 範囲で はすべて液晶相であり，耐熱性も低いままで変動しな かった. $37^{\circ} \mathrm{C}$ 培養細胞について 10 倍希釈法による加熱 によって観察された Fig. 2 の曲線的な耐熱性の予備保 温温度依存性は，加熱時の希釈倍率に影響を受け，100 倍希釈（予熱した緩衝液 $19.8 \mathrm{ml}$ に $0.2 \mathrm{ml}$ の菌懸濁液 を注入）による一層急速な加熱では $22^{\circ} \mathrm{C}$ 付近で急激に 生存率が低下し，それ以下の低温側でほぼ一定となる 不連続性が認められた。

このような現象は，野生株の培養温度変化の代わり に不飽和脂肪酸合成欠損株を用い，同じ培養温度の $30^{\circ} \mathrm{C}$ で添加不飽和脂肪酸種を変化（オレイン酸とリ） レン酸）させた場合にも認められ，オレイン酸培養で は膜脂質相分離開始（ゲル相が出現し始める）温度の $15^{\circ} \mathrm{C}$ 付近から低温になるにつれて 10 倍希釈法による加 熱後の生存性が次第に低下したが，相分離開始が $4{ }^{\circ} \mathrm{C}$ 付 近であるリノレン酸培養細胞ではほとんど影響を受け なかった。 なお，最近，筆者らは，この予備保温効果 には，熱作用の二次的な細胞膜損傷に起因するとみら れる活性酸素の発生が関与することを示唆している.

この定温での予備保温の代わりに，非定温加熱にお ける昇温速度を変えて検討したところ， $0^{\circ} \mathrm{C}$ かの緩慢 昇温はその速度が遅いほどその後の定温加熱による死 滅の速度が低下した。この現象を昇温効果とよび，速 度をさまざまに変化させて検討した結果，上記の予備 保温後の希䣋による比較的急速な昇温加熱領域（約 $30^{\circ} \mathrm{C} / \mathrm{min}$ 以上）とそれより緩慢な昇温領域（約 $30^{\circ} \mathrm{C} /$ min 以下）とでそれぞれ耐熱性変動の要因が異なるこ とを示唆した。急速加熱域では上記の細胞膜脂質の相 転移・相分離が関与するが，その効果には相分離が生 ずる温度範囲が存在し，昇温速度の効果は相分離の程 度によって決定されるとみられ，たとえば $37^{\circ} \mathrm{C}$ 培養の 大腸菌の耐熱性は $22^{\circ} \mathrm{C}$ 以下の温度範囲をどれだけの速 度で通過するかによって影響を受ける。しかし， $15^{\circ} \mathrm{C}$ 培養の場合は $0 \sim 37^{\circ} \mathrm{C}$ 範囲で相分離は発生しないた め，これに影響されないと推察された。一方，緩慢加 熱域では $37^{\circ} \mathrm{C}$ 以上から加熱温度近くに至るまでの高温 暴露による細胞の熱ショック応答に起因する熱適応 (熱 トレランス）が耐熱性化の要因と考えられた。同様な 現象は予備保温の代わりに加熱後の冷却温度について も得られた。

ここで得られた予備保温効果と昇温効果は，種々の 細菌・酵母の栄養細胞，卵白やトマトジュースなど種々 
の食品系でも観察され，低温加熱殺菌（パストゥリゼー ション) プロセスに打いて，効果の評価や予測に留意 すべき問題であることを指摘した。

\section{3. 加熱殺菌における薬剤併用効果の動力学的解析}

加熱殺菌では適当な薬剤を共存させると殺菌効果が 増大することが広く知られ，この併用処理は実際の食 品殺菌に扔いてしばしば利用されている．筆者ら [6-9] は，大腸菌をモデルに，食品防腐剂のソルビン酸と両 性界面活性剤（アルキルアミノエチルグリシン系のテ ゴー 15DL）の加熱併用殺菌効果について，加熱温度と 薬凨濃度を変動させて調べているうち，その特性が両 薬剤間で大きく異なることを見出した（Fig. 3).

一般に, 微生物の熱死滅は次の一次反応に従うこと が多い.

$$
\mathrm{d} N / \mathrm{d} t=-k N
$$

ここで, $N$ は生存数 $\left(\mathrm{ml}^{-1}\right), t$ は加熱時間, $k$ は死滅速 度定数 $\left(\min ^{-1}\right)$ である.

ソルビン酸あるいは両性界面活性剤が共存する場合, 熱死滅速度はそれらの添加濃度の上昇とともに増大し たが，その温度依存性に明らかな相違が認められた。

熱死滅速度の温度依存性は，一般の化学反応と同様 に次のアレニウス式

$$
k=A \cdot \exp (-E \mathrm{a} / R T)
$$

に従うことが知られ，ここで， $E \mathrm{a}$ は反応の活性化エネ ルギー $(\mathrm{kJ} / \mathrm{mole}), T$ は絶対温度 $(\mathrm{K}), R$ は気体定数, A は頻度因子（定数）である.

この死滅反応の活性化エネルギーの值が, ソルビン 酸の場合には調べた $0.5 \sim 3 \%$ の範囲の各濃度について
あまり差がなかったが，両性界面活性刋では，1〜 $10 \mu \mathrm{g} / \mathrm{ml}$ の範囲で濃度の上昇とともに顕著に低下した。 Fig. 3（図はほぼ同様な傾向を示す下記のアイリングの 式に基づくプロット）にみられるように，両性界面活 性剤では各直線を高温側に外挿するとおおざっぱにみ て実験域に近い温度で交差する傾向にあって，その温 度を平均值として求めることができるが，後者では平 行関係にあるため，測定不可能であった．

死滅反応の温度依存性は絶対反応速度論におけるア イリングの式

$$
k=\left(k_{B} T / h\right) \cdot \exp \left(-\Delta H^{*} / R T\right) \cdot \exp \left(\triangle S^{*} / R\right)
$$

によっても表される。ここで， $\Delta H^{*} ， \Delta S^{*}$ はそれでれ 反応の活性化エンタルピーと活性化エントロピー, $k_{B}$ はボルツマン定数, $h$ はプランク定数である.

さらに，両性界面活性剤による熱死滅促進に打いて， 死滅反応の $\Delta H^{*} に$ 対して $\Delta S^{*}$ を各薬剤濃度についてプ ロットすると直線が得られたことから， $\Delta H^{*}-\Delta S^{*}$ 補 償効果

$$
\Delta S^{*}=\left(1 / T_{\mathrm{c}}\right) \Delta H^{*}+b
$$

を確認した，ここで， $T_{\mathrm{c}}$ は補償温度とよばれ， $b$ は定 数である. 得られた直線の傾きから補償温度を求めた 結果，上述のアレニウスプロットに打ける交差点の温 度に近い $61^{\circ} \mathrm{C}$ となった，理論上は，この温度で併用効 果は消失することになる。ソルビン酸の場合はそれら の熱力学的変数があまり変化しないため，補償温度は 求められなかった.

一方，薬剤の熱死滅促進効果を，古くから知られて いる薬剤殺菌に打ける経験式

$$
k=B \cdot C^{n}
$$

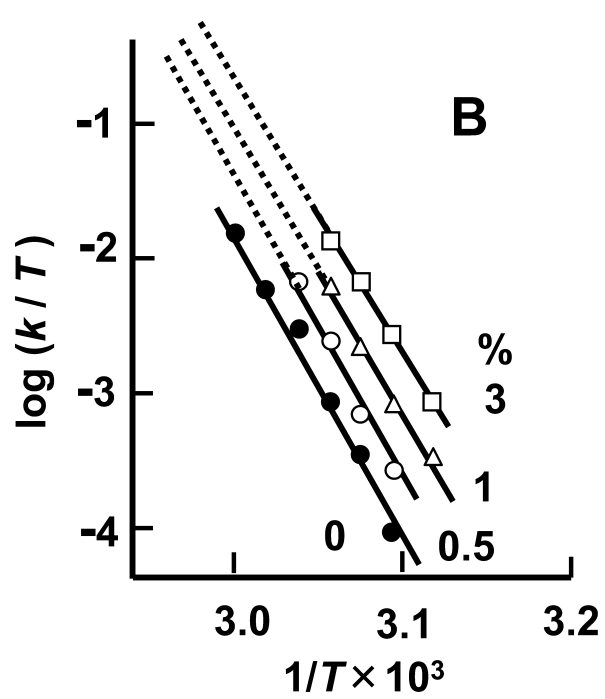

Fig. 3 Arrhenius plots for the thermal death of E. coli in the presence of an amphoteric surfactant Tego 15DL (A) or sorbic acid (B). Concentrations used are indicated in the figure. 
に基づいて解析した。ここで， $C$ は薬剤濃度， $n$ は殺菌 濃度指数， $B$ は定数である。この式に基づいて薬郕濃 度と死滅速度定数の両対数プロットをとると直線が得 られ，その傾きから殺菌濃度指数が求まる。 この值は, ソルビン酸では加熱温度によらずほぼ一定であったが, 両性界面活性剤では加熱温度の上昇とともに低下した ことから，ソルビン酸の熱死滅促進勃果は加熱温度に ほとんど依存しないが，両性界面活性剤の場合は高温 側よりも低温側で顕著であることがわかった（Fig. 3).

薬剤と加熱の併用殺菌効果について，加熱温度と薬 剤濃度の両方の影響を系統的に検討した例は予想外に 少ない。そこで筆者らは，それらを上記の動力学的特 性に基づいて評価し，加熱併用殺菌効果を示す薬剛は, 一般にソルビン酸のような挙動をとる酸（A）型と両性 界面活性剤に類似した挙動を示す界面活性剂（S）型の 2 つに類型化できることを提唱した.

また，この類型の違いの要因を解析するため，大腸 菌の熱死滅における炭素鎖長の異なる脂肪酸の促進効 果を系統的に調査した結果，カプロン酸（C6）はA 型 であるが，カプリル酸 (C8)，カプリン酸 (C10)， ラ ウリン酸（C12）は S 型に属することがわかった。この ことは，薬剤分子の疎水性が細胞の熱死滅促進作用に 関係することを示唆しており，打そらく細胞膜への作 用の有無が関わるものと推察された。乳化剂のモノラ ウリンについても特性を検討し，S 型に属することを認 めた。

\section{4. 新規な殺菌・細胞損傷効果の評価法の開発}

殺菌効果の評価には，培養法と非培養法があり，培 養法では一般的に平板法が古くから用いられているが, 煩雑な希釈操作を必要とするため, 近年では ATP 定量, 細胞内特定酵素の活性測定や色素の透過性など，非培 養法に該当する新規な迅速法・簡便法が多く開発され

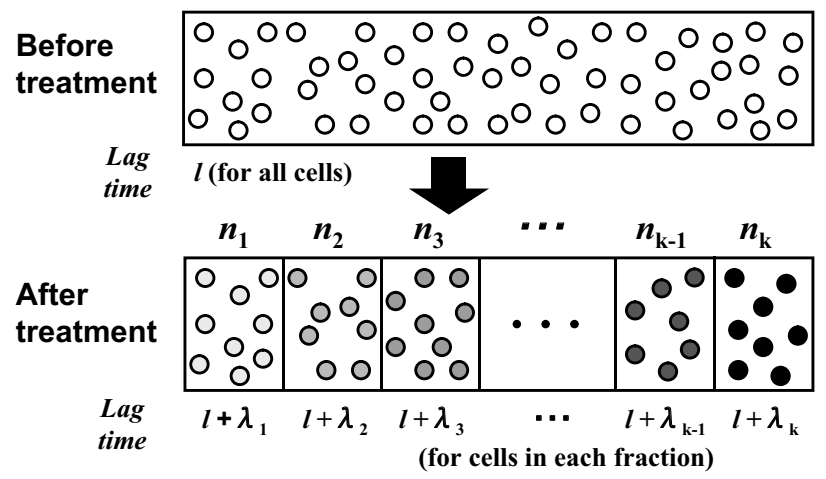

Fig. 4 A model of the injury distribution in a stressed cell population exposed to a lethal treatment. Each cell in a fraction of the population, $n_{\mathrm{i}}$, has a lag time, $l+\lambda \mathrm{i}(i=1,2$, $\cdots, k)$
ている。これらの方法に打ける細胞の生死判定は，そ れぞれの測定原理に依存するため，当然得られる結果 は異なる。筆者らは，培養法であるが操作が簡便な発 育遅延時間解析法と非培養法で顕微鏡像の画像処理に 基づく細胞運度速度解析法および細胞内に予め合成さ せた緑色蛍光タンパク質（GFP）を利用する蛍光法に ついてそれらの有効性を検討した。

\section{1 発育遅延解析による評価法 [10-12]}

この方法は，未処理細胞集団に対する処理集団の発 育遅延時間差から殺菌率を求めるもので，微生物の損 傷による発育遅延分布の概念をもとに，その基盤とな る理論を以下のとおり構築した。

微生物集団は殺菌処理前でも細胞周期によって個々 の細胞の処理耐性は異なっていると考えられるが，乇 デルを単純にするためそれぞれの発育のための誘導期 は同じ時間 $l(\mathrm{~h})$ であると仮定する (Fig. 4).この集 団を殺菌処理にさらすと，一部の亜集団 $\left(n_{\mathrm{k}}\right)$ は不可 逆的に死に至るとみられるが，その他の集団は処理の 程度に応じて軽傷のもの $\left(n_{1}\right)$ から重傷のもの $\left(n_{\mathrm{k}-1}\right)$ までいくつかの亜集団に分かれ，これらの亜集団は処 理後適当な条件に置かれることによって回復できるも のと仮定する．処理集団に打いては，損傷回復に必要 な誘導期とその延長時間 $\left(l+\lambda_{\mathrm{i}}\right)$ は, Fig. 4 に示すよう に分布することを想定する.

この処理集団を液体培地に移し，濁度（OD）測定な どの方法によってその後の発育を追跡すれば，Fig. 5a のような発育曲線が得られる。この場合，無傷集団と 処理集団は，同一の比発育速度 $\mu\left(\mathrm{h}^{-1}\right)$ で発育すると仮

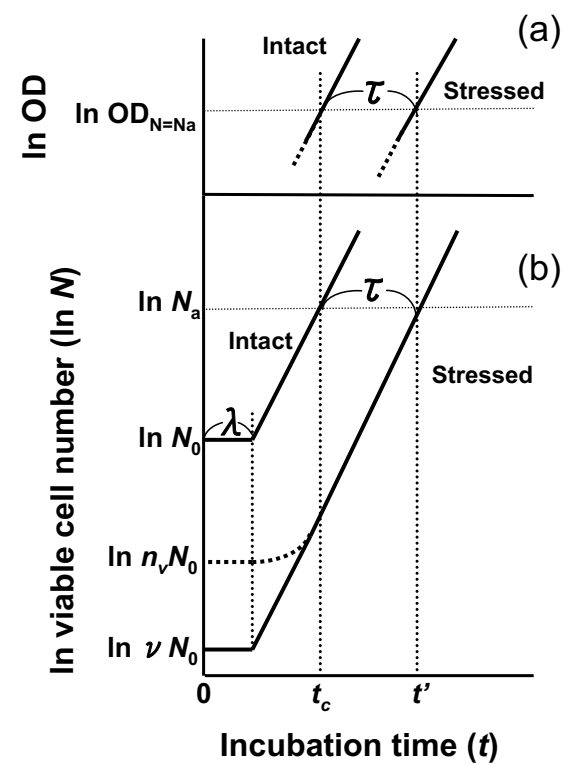

Fig. 5 Growth curves of intact and stressed cell populations as measured by optical density (a) and as supposed with the real number of survived cell (b). 
定すると，それらの発育曲線はそれぞれ，式(1)と (2) で示される.

$$
\begin{gathered}
N=N_{0} \exp [\mu(t-l)] \\
N=N_{0} \sum_{i=1}^{k} n_{\mathrm{i}} \cdot \exp \left[\mu\left(t-l-\lambda_{\mathrm{i}}\right)\right]
\end{gathered}
$$

ここで，各亜集団の $\lambda$ は， $0<\lambda_{1}, \lambda_{2}, \cdots, \lambda_{\mathrm{k}-1} \ll \infty ， ま$ た $\lambda_{\mathrm{k}} \fallingdotseq \infty$ とおくことができ，

$$
\sum_{i=1}^{k} n_{\mathrm{i}}=1
$$

また， $k$ 番目の亜集団は死滅したものとすれば，生存数 は 1 から $k-1$ 番目までの亜集団となり，これを生存割 合 $n_{\mathrm{v}}$ とすれば，式(4)のようになる.

$$
\sum_{i=1}^{k-1} n_{\mathrm{i}}=n_{\mathrm{v}}
$$

ここで，換算生存率レを下記の式 (5) によって定義する

$$
\nu=\sum_{i=1}^{k} n_{\mathrm{i}} \cdot \exp \left(-\mu \lambda_{\mathrm{i}}\right)=\sum_{i=1}^{k-1} n_{\mathrm{i}} \cdot \exp \left(-\mu \lambda_{\mathrm{i}}\right)
$$

一般には $\lambda_{\mathrm{i}}>0$ なので，

$$
\nu<n_{\mathrm{v}}
$$

式 (5)を式 (2)に代入することにより，処理集団の生存 数は式 $(6)$

$$
N=\nu N_{0} \exp [\mu(t-l)]
$$

となり，これを式 (1) と比較することによって，Fig. 5b に示したように，処理によって生存数が初発值 $N_{0}$ から $\nu N_{0}$ に低下したとみなせる。そこで，Fig. 5 に示すよ うに，対数期のある一定の菌数 $N_{\mathrm{a}}$ に達する時間を無傷 集団について $t_{\mathrm{c}}$ ，処理集団は $t^{\prime}$ とすれば，式 (1) と式 (6) は，それぞれ，

$$
\begin{gathered}
N_{\mathrm{a}}=N_{0} \exp \left[\mu\left(t_{\mathrm{c}}-l\right)\right] \\
N_{\mathrm{a}}=\nu N_{0} \exp \left[\mu\left(t^{\prime}-l\right)\right]
\end{gathered}
$$

となる. 式 (7) と (8) から,

$$
\nu=\exp \left[-\mu\left(t^{\prime}-t_{\mathrm{c}}\right)\right]
$$

処理集団の無傷集団に対する発育遅延時間を Fig. 5 に 示すように $\tau(h)$ とおくと，

$$
\nu=\exp (-\mu \tau)
$$

すなわち,

$$
-\log \nu=\mu \tau / 2.303
$$

ここで，無傷集団について，接種菌数を 10 倍ごと希釈 して培養すると $N_{\mathrm{a}}$ に到達する時間 $t_{\mathrm{c}}$ は一定時間ごとに 遅延する，そこで，初発生存数 $N_{0}$ を $N_{0}$ としたときの $t_{\mathrm{c}}$ を $t_{\mathrm{c}}$ とし，そのときの発育遅延時間を $\tau_{\mathrm{c}}$ とすると，

$$
\log \left(N_{0}{ }^{\prime} / N_{0}\right)=\mu\left(t_{\mathrm{c}}{ }^{\prime}-t_{\mathrm{c}}\right)=-\mu \tau_{\mathrm{c}}
$$

そして，無傷集団の接種菌数を 1 桁低下させて培養し たときの発育遅延時間を $G_{10}(\mathrm{~h})$ と定義すると， $N_{0}{ }^{\prime}=$ $N_{0} / 10$ のとき， $\tau_{\mathrm{c}}=G_{10}$ となり，これを式(10)に代入し $\tau$,

$$
\mu \cdot G_{10}=2.303
$$

式 $(10)$ が処理集団についても成立し， $\mu\left(G_{10}\right)$ が無傷集 団のそれとほぼ同じであることを確認すれば，式 (11) と式(9)から

$$
-\log \nu=\tau / G_{10}
$$

となる。

つまり，式(5)によって生存割合とその誘導期延長時 間の関数として定義された換算生存率 $\nu$ の対数的低下 は，式(12)で表されるように，殺菌処理による発育遅 延時間 $\tau$ を接種菌数の $1 / 10$ 低下による発育遅延時間 $G_{10}$ で除したものとして表記できる。この方法の適用に あっては上述のいくつかの条件を満足する必要がある が，少なくとも物理的な殺菌処理の場合はほぼ問題な く適用できる。

この方法が平板法に勝る最大の利点は，自動発育測 定装置を用いることによって極めて簡便に結果が得ら れ，独立した細胞だけでなく集合性のものや菌糸状の ものでも適用可能なことである (Table 1)，筆者らの研 究室では，最大 48 本の試料について培養とその間の濁 度変化が最短 2 分程度の間隔で測定可能なバイオスキャ ナー（大岳製作所製 OT-BS-48）を用い，処理後の各 試料をこの装置にまとめてセットして培養と濁度測定 を開始し, 翌日各データを発育遅延時間計測ソフトウェ アによってコンピュータ处理し，即座に $\tau$ を求めてい る. 生存率の結果としては，一般に，細胞損傷の回復 に時間的余裕を与える平板法よりもやや低い值が得ら れることが多い。

なお，ここでは省略するが，薬郕や食塩など発育阻 害作用をもつ化合物が解析用培地に含まれる場合につ いても検討し，その生存率低下の理論を導出した [11].

\section{2 細胞運動速度法 [13-15]}

運動能をもつ細菌は，鞭毛によって移動するが，そ のエネルギー源は細胞膜を介したプロトン勾配である. 細胞が殺菌処理にさらされて損傷を受けると，その工 ネルギーレベルが低下し，そのため運動の速度も低下 する。鞭毛は左回転して細胞が直進泳行し，右回転で 移動停止してタンブリングとよばれる方向転換をする. 細胞は，この鞭毛の 2 つの回転モードを繰り返して移 動するが，変異処理によってタンブリング能を欠損さ せた細胞では，運動速度は処理による損傷の程度に直 
Table 1 Advantages and disadvantages of the growth-delay analysis method and the bacterial motion analysis method in comparison with colony counting method.

\begin{tabular}{|c|c|c|}
\hline Item & $\begin{array}{l}\text { Growth-delay analysis method } \\
\text { (Growth method) }\end{array}$ & $\begin{array}{l}\text { Bacterial motion method } \\
\text { (No-growth method) }\end{array}$ \\
\hline Advantage & $\begin{array}{l}\text { - Simple (not necessary for dilution and } \\
\text { plating) } \\
\text { - Small experimental errors } \\
\text { - Many samples simultaneously available } \\
\text { - Applicable for chain-forming, clustering or } \\
\text { mycelial-type cells } \\
\text { - Applicable to other growth assay methods } \\
\text { available besides turbidity }\end{array}$ & $\begin{array}{l}\text { - Rapidly measurable (about } 1 \mathrm{sec} / \mathrm{screen} \text { for } \\
\text { measurement, about } 2 \text { min for data analysis and } \\
\text { about } 3 \text { min for sample preparation) } \\
\cdot \text { Evaluation possible for both individual cell and } \\
\text { cell mass levels } \\
\cdot \text { Low running cost } \\
\cdot \text { Simple operations }\end{array}$ \\
\hline Disadvantage & $\begin{array}{l}\text { - Time-consuming (cultivation necessary) } \\
\text { - Install cost necessary for an apparatus for } \\
\text { measurement } \\
\text { - Computer software necessary for analysis } \\
\text { of delay-time }\end{array}$ & $\begin{array}{l}\text { - Not available for non-motile, easily attaching, and } \\
\text { morphologically changing microorganisms } \\
\text { - Distribution of motion speed in a cell population } \\
\text { - Install cost necessary for an image analyzer for } \\
\text { measurement } \\
\text { - Restriction of three-dimensional motion. }\end{array}$ \\
\hline
\end{tabular}

接対応して変化する.また, 運動能を全く失ったもの(ブ ラウン運動レベル）を死菌，運動性を保持しているも のを生菌と定義できる.

ここで開発した方法は，枯草菌や大腸菌のタンブリ ング能欠損株を検定菌として用い，殺菌処理後，光学 顕微鏡下にその運動画像軌跡の解析によって運動速度 を計測し，細胞の死滅や損傷の評価に応用するもので ある. 最大の長所は， 0.05 秒間隔で 1 分間程度の画像 計測を行うので極めて迅速な評価ができることである. 欠点としては，上記検定菌を使用するのでなければ， 運動性細菌でしかもタンブリング能欠損株を取得する 必要があること，運動速度は細胞間で分布があるため 最低 50 細胞くらいを対象に計測する必要があることで ある（Table 1).

\section{3 緑色蛍光タンパク質利用蛍光法 [16-17]}

種々の殺菌処理における細菌胞子や栄養細胞の死滅 · 損傷過程を迅速に評価するため, 市販の緑色蛍光タン パク質（GFP）をもとに，それを耐熱性化したものや $\mathrm{pH}$ ，塩濃度，酸化などを感知する各種の GFP 変異体を 作製し，それらを胞子コアや細胞内に発現させ，処理 中のそれらの蛍光の変化を解析した。

細菌胞子の場合, ベクター pET21a 内でシグマ G 因 子支配下の $s s p B$ 遺伝子のプロモーターの下流に GFP 変異体の遺伝子を連結してコア内に発現させた。その 1 つの YFP3.2 発現胞子を用いて加熱処理を行ったとこ ろ，その初期過程では胞子コアへの水の浸入に伴うと みられる蛍光上昇が，そしてその後に発現タンパク質 の変性によると推察される蛍光低下がみられ，反応速 度の解析によって両反応の特性を明らかにした。また， 次項に述べる酸化系殺菌剤による胞子コア内の酸化も roYFP 1 と命名した GFP 変異体の酸化による 2 量体化
によって評価することができた。

大腸菌においても外膜，ペリプラズム，内膜，細胞 質にそれぞれ発現・局在化させた GFP 変異体を用い， 加熱や食塩ショックによる局所的な損傷を解析して有 用な知見を得た。

現在，上述の一般的なレポーター用のものや細胞内 局在型のほかに，目的に応じて FRET（蛍光共鳴エネル ギー移動）型やプロモーターアッセイ型など，新たに 種々の GFP 変異体を構築中であり，それらを様々な殺 菌効果の評価に用いるべく実用化を図るとともに，胞 子や細胞の損傷 ·修復の反応特性の解析に利用すべく 検討を進めている.

\section{5. 加熱殺菌における微生物死滅データベースの 作成と予測微生物学的アプローチ}

近年，食品製造における HACCP（危害分析重要管理 点）システムの導入が進展しつつあり，食品の微生物 的安全性について無菌試験などの事後評価方式から, 微生物の死滅挙動を予め推定したモデリング技術を取 り入れ，加熱温度や時間などの条件管理に基づく事前 予測方式に移行する方向にある。この目的で，殺菌の データベースの構築とそれに基づく微生物挙動の数学 モデルの開発が進みつつあり，その最初の実用的なも のとして，イギリス政府研究機関を中心にフードマイ クロモデルが発表された。筆者らのグループとアメリ 力農務省は，ほぼ時を同じくしてデータベースの構築 を始め，その後も拡大・充実化を進めており，各国研 究機関に打いてもそれぞれ特徴的なモデリングの取り 組みがなされている.

1996 年から取り組みを始めた筆者ら [18-19] の加熱 殺菌データベースである「サーモキル・データベース $\mathrm{R} 」$ 
は，食品工場の殺菌工程管理や商品開発などの際の標 的微生物に関する殺菌条件設計での実用に供すること を目的として作製したものである。これは，主要学術 誌に発表された過去の論文から種々の実験条件データ と死滅データを抽出し，種々の食品や微生物など 65 に 及ぶ項目について収集，整理し，検索可能としている。 検索用画面の例を Fig. 6 に示す。これまで 1991 年から 2000 年の発表論文をべースとしたR9100，つづいて 1981 年からのものを併合した R8100を発表し，さらに 最新版の 1981 年 2005 年版の $R 8105$ が完成している. この最新版では，レコード数が 12,000 余り，D值数は 17,000 余りを収載している（データベースのウェブサ イトは http://www.h7.dion.ne.jp/ tbx-tkdb/). 現在で は，薬剤殺菌データベースの構築も始めている.

様々な条件での微生物の増殖や死滅の挙動を予測す る手法は，予測微生物学としてその活用が有望視され ている．筆者ら [20-22] は，緩衝液系と食品系を用い， 加熱殺菌に打ける枯草菌胞子の非対数的熱死滅に対す る加熱温度, $\mathrm{pH}$ や塩濃度の影響について，線形ビゲロ ウモデルやワイブルモデルを用いた死滅予測モデルを 提示するとともに，先のサーモキル・データベース $\mathrm{R}$ によってそれらの結果を検証した。

\section{6. 謝辞}

筆者は，長年殺菌を含めた微生物制御の分野で活動 してきたが，このたび思いがけず本学会の学会賞を受 賞し，身に余る光栄と感じている．日本食品工学会の
関係各位に深甚の謝意を表するとともに，会員の皆様 方に厚く御礼を申し上げたい。

また，本研究の推進にあたり，ご指導・ご助言いた だいた大阪大学芝崎勲名誉教授，同高野光男名誉教授 をはじめ多くの先生方に深謝申し上げる。また，研究 に協力いただいた中村一郎聖母女学院短期大学教授を はじめ, 関西大学の松村吉信准教授, 坂元 仁研究員, Aswathanarayana Jagannath ポスドク研究員，阿部智子 氏，また実験に携わっていただいた大阪大学と関西大 学の多くの学生諸君と研究補佐をいただいた関係各位 に感謝申し上げたい。さらに，受託研究や共同研究で 実用上の問題解決に関わる研究テーマを与えていただ き，多くのご示唆をいただいた関係企業の方々に厚く お礼申し上げる。

\section{引用 文 献}

1) T. Tsuchido; Studies on microbiological basis of microorganism control-Stress microbiology and control of microorganisms (in Japanese). J. Antibacterial Antifungal Agents, 32, 251-263 (2004).

2) T. Tsuchido, M. Takano, I. Shibasaki; Effect of temperatureelevating process on the subsequent isothermal death of Escherichia coli K-12. J. Ferment. Technol., 52, 788-792 (1974).

3) N. Katsui, T. Tsuchido, M. Takano, I. Shibasaki; Effect of preincubation temperature on the heat resistance of Escherichia coli having different fatty acid compositions. J.

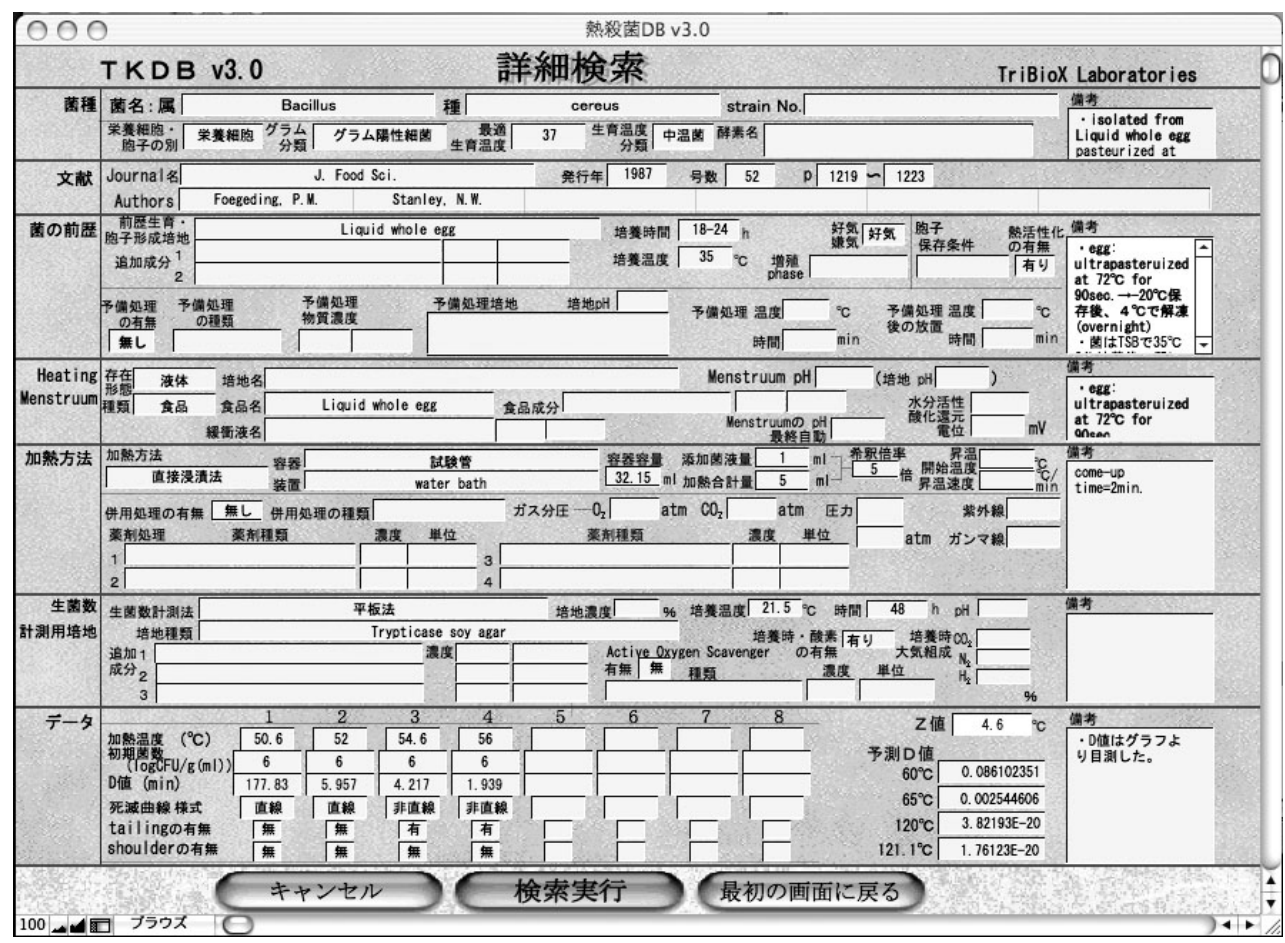

Fig. 6 An example of the screen for presentation of data in "ThermoKill Database R". 
Gen. Microbiol., 122, 357-361 (1981).

4) T. Tsuchido, M. Hayashi, M. Takano, I. Shibasaki; Alteration of thermal resistance of microorganisms in a nonisothermal heating process. J. Antibacterial Antifungal Agents, 10, 105-109 (1981).

5) N. Katsui, T. Tsuchido, M. Takano, I. Shibasaki; Viability of heat-stressed cells of microorganisms as influenced by preincubation and postincubation temperatues. J. Appl. Bacteriol., 53, 103-108 (1982).

6) Tsuchido, I. Shibasaki; Kinetics of microbial death by combined treatment with heat and antimicrobial agents. Biotechnol. Bioeng., 22, 107-118 (1980).

7) T. Tsuchido, T. Saeki, I. Shibasaki; Death kinetics of Escherichia coli in a combined treatment of heat and monolaurin. J. Food Safety, 3, 57-68 (1981).

8) H. Yamanaka, T. Tsuchido; Death kinetics for Escherichia coli cells heated in the presence of short- and mediumchain fatty acids. Biocontrol Sci., 5, 17-23 (2000).

9) T. Tsuchido; Combined effects of antimicrobial agents and heating on microorganisms. A monograph (in Japanese). Hakkokogaku, 55, 144-155 (1977).

10) M. Takano, T. Tsuchido; Availability of growth delay analysis for the evaluation of total injury in stressed bacterial population. J. Ferment. Technol., 60, 189-198 (1982).

11) T. Tsuchido, T. Koike, M. Takano; A modified assessment of growth inhibition from growth-delay time in a cell population exposed to an environmental stress. J. Ferment. Bioeng., 67, 132-134 (1989).

12) T. Tsuchido; A simple viability measurement for microorganism control. A theory and application of the growth-delay analysis method (in Japanese). Gien, 71, 59-62 (1992).

13) T. Tsuchido, H. Takecuhi, H. Kawahara, H. Obata; Evaluation of bacterial injury by image analysis of cell motion. J. Ferment. Bioeng., 78, 185-187 (1994).

14) T. Tsuchido, K. Yasunaga, Y. Matsumura, K. Oku; Efficacy evaluation of antimicrobial compounds by dynamic image analysis of bacterial motion. In "Biodeterioration and Biodegradation" (Proc. 10 $0^{\text {th }}$ Int. Biodeterioration Biodegradation Symp., Hamburg), Ed. by W. Sand, pp.45-50 (1996).

15) T. Tsuchido, K. Yasunaga, Y. Matsumura, K. Oku; Use of a tumbling-defective mutant of Escherichia coli for evaluation of pollutant toxicity by dynamic image analysis of bacterial motion. Biocontrol Sci., 1, 61-63 (1996).

16) T. Tsuchido, J. J. Sakamoto; Killing of bacteria by induction of membrane damage and its monitoring as a membranestress biotechnology (in Japanese). Seibutsukogaku-kaishi (J. Soc. Biotechnol.), 82, 193-196 (2004).
17) T. Tsuchido, J. J. Sakamoto; An outline of stress microbiology for control of harmful microorganisms (in Japanese). Jpn. J. Food Microbiol., 26, 70-75 (2009).

18) I. Nakamura, T. Yokohara, T., T. Tsuchido; Database of microbial thermal death. Its construction design based on data from published papers and from experiments performed under defined conditions. Biocontrol Sci., 5, 61-64 (2000).

19) T. Abe, I. Nakamura, T. Yokohara, Y. Omura, T. Hiraga, T. Tsuchido; Construction of ThermoKill Database R8100, an expanded version of a microbial thermal death database developed on the basis of information in research papers published from 1981 to 2000. Biocontrol Sci., 12, 35-38 (2007).

20) A. Jagannath, I. Nakamura, T. Tsuchido; Modelling the combined effect of $\mathrm{pH}$, temperature, and sodium chloride stresses on the thermal inactivation of Bacillus subtilis spores in a buffer system. J. Appl. Micribiol., 95, 135-141 (2003).

21) A. Jagannath, T. Tsuchido; Validation of a polynominal regression model: The thermal inactivation of Bacillus subtilis spores in milk. Lett. Appl. Microbiol., 37, 399-404 (2003)..

22) A. Jagannath, T. Tsuchido, J.-M. Membre; Comparison of the thermal inactivation of Bacillus subtilis spores in foods by using the modified Weibull and Bigelow equations. Food Microbiol. 22, 233-239 (2005).

\section{要旨}

食品殺菌プロセスは, マクロ的視点に立つ工学とミ クロ的立場からの微生物学が融合してこそ，より信頼 性の高い評価や予測が可能となると考えられる。本稿 では，それらの接点に位置づけられるいくつかの局面 において筆者らが進めてきた研究成果を概説した。加 熱殺菌に打ける昇温過程の解析では, 大腸菌の熱死滅 に対して予備保温が影響する現象を見出し，これには 細胞膜脂質の相転移・相分離が関与すること，またこ れが非定温過程における昇温速度の効果に反映される ことを明らかにした。加熱殺菌に打ける薬剤併用効果

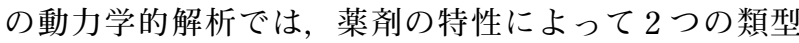
化が可能なことを示した。新規な殺菌および細胞損傷 評価法の開発では，発育遅延解析による評価法，細胞 運動速度法，緑色蛍光タンパク質利用による蛍光法を 提唱し，それぞれの特性と有用性を提示した。加熱殺 菌に打ける微生物死滅データベースと予測微生物学的 アプローチでは，それぞれ実用化のための開発の経緯・ 内容と検討例の概要を紹介した。 